\title{
Identification of canine papillomavirus type 1 (CPV1) DNA in dogs with cutaneous papillomatosis ${ }^{1}$
}

\author{
Brígida K. de Alcântara², Amauri A. Alfieri²*, Wagner B. Rodrigues², Rodrigo A.A. \\ Otonel $^{2}$, Michele Lunardi ${ }^{2}$, Selwyn A. Headley ${ }^{3}$ and Alice F. Alfieri ${ }^{2}$
}

\begin{abstract}
De Alcântara B.K., Alfieri A.A., Rodrigues W.B., Otonel R.A.A., Lunardi M., Headley S.A. \& Alfieri A.F. 2014. Identification of canine papillomavirus type 1 (CPV1) DNA in dogs with cutaneous papillomatosis. Pesquisa Veterinária Brasileira 34(12):12231226. Laboratório de Virologia Animal, Departamento de Medicina Veterinária Preventiva, Universidade Estadual de Londrina, Rodovia Celso Garcia Cid, Campus Universitário, Cx. Postal 10011, Londrina. PR 86057-970, Brazil. E-mail: alfieri@uel.br

Canine oral papillomavirus (COPV), also known as Canine Papillomavirus type 1 (CPV1), induces papillomas at the mucous membranes of the oral cavity and at the haired skin of dogs. The classification of Papillomavirus (PV) types is based on the L1 capsid protein and nucleotide sequence; so far, $14 \mathrm{CPV}$ types have been described in several countries, but the molecular characterization of CPV in Brazil is lacking. This study investigated the presence of the PV in seven papillomas from four mixed breed dogs from Londrina/PR, Southern Brazil, by partial sequencing of the L1 gene. Seven exophytic cutaneous lesions were surgically removed and processed for histopathological and molecular characterization. Histopathology confirmed the lesions as viral papillomas due to typical histological features. Polymerase Chain Reaction (PCR) assay using the FAP59 and FAP64 primers targeted the L1 gene followed by sequence analysis of the amplicons identified CPV1 in all evaluated papilloma samples. This study represents the first description of CPV1 DNA associated with canine papillomatosis in Brazil.
\end{abstract}

INDEX TERMS: Papillomatosis, canine, CPV1, papilloma, warts, L1 gene.

RESUMO.- [Identificação do DNA de Papillomavirus canino tipo 1 em cães com papilomas cutâneos no Brasil.] O papilomavírus oral canino (COPV), também denominado Papillomavirus canino tipo 1 (CPV1), tem a capacidade de induzir papilomas na mucosa da cavidade oral e também em pele de cães. A classificação dos tipos de papilomavírus (PV) é baseada na proteína L1 do capsídeo e na sequência de nucleotídeos que a codifica. Atualmente são descritos 14 tipos de CPV, no entanto, ainda faltam estudos moleculares relacionados à identificação dos tipos de CPV no Brasil. 0 objetivo deste estudo foi investigar a presença de PV em fragmentos de papilomas obtidos de quatro cães sem raça

\footnotetext{
${ }^{1}$ Received on June 2, 2014.

Accepted for publication on August 15, 2014.

${ }^{2}$ Laboratório de Virologia Animal, Departamento de Medicina Veterinária Preventiva (DMVP), Universidade Estadual de Londrina (UEL), Rodovia Celso Garcia Cid, Campus Universitário, Cx. Postal 10011, Londrina, PR 86057-970, Brazil. *Corresponding author: alfieri@uel.br

${ }^{3}$ Laboratório de Patologia Veterinária, DMVP-UEL, Rodovia Celso Garcia Cid, Campus Universitário, Cx. Postal 10011, Londrina, PR.
}

definida, provenientes de Londrina/PR, região sul do Brasil, e definir o tipo viral por meio da análise da sequência parcial de nucleotídeos do gene L1. Sete lesões cutâneas foram cirurgicamente removidas e processadas para a caracterização histopatológica e molecular. 0 exame histopatológico confirmou as lesões como papilomas. Foi realizada reação em cadeia de polimerase (PCR), utilizando os primers FAP59 FAP64 para a amplificação parcial do gene L1, seguida por análise das sequências dos produtos amplificados, que confirmou a presença do CPV1 em todas as amostras avaliadas. Este estudo representa a primeira identificação do DNA de CPV1 associado com papilomatose canina no Brasil.

TERMOS DE INDEXAÇÃO: Papilomatose, canina, CPV1, papiloma, verrugas, gene L1.

\section{INTRODUCTION}

The Papillomavirus (PV) is a group of DNA viruses that induces benign and malignant proliferative lesions at the epidermis and mucous membranes of their natural hosts, and probably occur in most mammals and birds (De Villiers et al. 2004). 
The classification of the papillomavirus types is based on the L1 nucleotide sequence. The L1 gene is highly conserved, and a new putative PV type is considered when the L1 nucleotide sequence is at least 10\% different from other PV types (De Villers et al. 2004). Based on this classification more than 200 types of PVs were characterized, most being isolated from humans (Bernard et al. 2010); currently 14 types of canine papillomavirus (CPVs) have been identified (Yuan et al. 2012a, Lange et al. 2013).

Moreover, CPVs can be allocated into three distinct Papillomavirus genera: Lambdapapillomavirus (CPVs 1 and 6); Taupapillomavirus (CPVs 2, 7 and 13); and Chipapillomavirus (CPVs 3, 4, 5, 8, 9, 10,11, and 14), while CPV 12 is not currently classified into a definite genus (Bernard et al. 2010, Lange \& Favrot 2011, Lange et al. 2012).

CPV1, originally denominated canine oral papillomavirus (COPV) (Bernard et al. 2010), induces papillomas at the mucous membranes of the oral cavity and at the haired skin of dogs (Gross et al. 2005); papillomas may progress to squamous cell carcinoma (Teifke et al. 1998). Additionally, CPV1 has been associated with inverted papillomas (Lange et al. 2009), and conjuctival epithelial hyperplastic lesions (Brandes et al. 2009) in dogs.

CPV2 has already been isolated from exophytic and endophytic papillomas as well as invasive squamous cell carcinoma, CPV6 was isolated from endophytic papilloma, and CPV7 from an exophytic lesion (Lange \& Favrot 2011). CPVs $3,4,5,8,9,10,11$, and 14 are associated with the development of pigmented plaques (Lange et al. 2013). Additionally, CPV13 was identified in oral papillomas (Lange et al. 2012). Moreover, the histopathological characterization of canine viral papilloma is obtained by the finding of typical viral-induced alterations in the cytoplasm and/or nucleus of affected cells (Gross et al. 2005, Lange \& Favrot 2011). The role of CPV12 as a pathogen of papillomatosis has not been elucidated (Yuan et al. 2012b unpublished data).

Isegawa et al. (1994) revealed that the CPV1 Ll gene was more closely related with human papillomavirus type 1 (HPVlA) and animal PVs associated with cutaneous lesions in the rabbit, European elk, deer, and cattle. Consequently, CPV1 has been used as a model for animal and human PVs infection and vaccine trials (Campo 2002).

Although oral papillomas were described in dogs from Brazil (Souza et al. 2006, Bianchi et al. 2012), molecular studies that characterized the PVs types in canine papillomas from Brazil were not located. This study investigated the occurrence of the CPV DNA in papillomas of dogs from Brazil by using the partial L1 gene amplification and sequence analysis.

\section{MATERIALS AND METHODS}

Dogs, cutaneous lesions, and sampling. Cutaneous lesions, clinically classified as papillomas, were surgically removed and collected from four mixed breed dogs. The lesions were surgically removed at the veterinary hospital, according with the protocols of animal welfare. All tissue samples were divided into two sections; one fixed in $10 \%$ neutral buffered formalin solution and routinely processed for histopathological evaluation, and the other maintained at $-20^{\circ} \mathrm{C}$ until used for molecular diagnosis.
DNA extraction, PCR, and sequencing. DNA was extracted from all samples by using the Qiagen DNeasy tissue kit (Qiagen Sample and Assay Technologies, Hilden, Germany). A negative control without tissue was included in all procedure to monitor possible contamination.

The PCR assay was done by using primers FAP59 and FAP64 designed to amplify a 480 base pair (bp) fragment of the PV L1 gene (Forslund et al. 1999), with modifications (Claus et al. 2007). All PCR products were analyzed by electrophoresis in $2 \%$ agarose gel, stained with ethidium bromide, and visualized under UV light.

The PCR products were purified by the using Illustra GFX PCR DNA and Gel Band Purification kit (GE Healthcare, Little Chalfont, UK). Direct sequencing was then performed using the DYEnamic ET dye terminator cycle sequencing kit (GE Healthcare, Little Chalfont, UK) with forward and reverse primers, in the $3500 \mathrm{Ge}$ netic Analyzer (Applied Biosystems, Carlsbad, USA). The obtained sequences were examined with the PHRED software for quality analysis by chromatogram readings. The sequences were accepted if the base quality was equal to or higher than 20. Consensus sequences were obtained by using the CAP3 software, and the sequence identity was compared with similar sequences deposited in the GenBank by using the BLAST software. The guidelines of the Papillomavirus Nomenclature Committee 1995 (14th International Papillomavirus Conference, Quebec City, Quebec, Canada) were used to identify PV types (De Villiers et al. 2004).

A multiple alignment was performed by using CLUSTAL W (version 1.4) within the MEGA 5.1 software; a sequence identity matrix was generated by using BioEdit software version 7.0.8.0. Phylogenetic trees were reconstructed by the maximum-likelihood method and distances were estimated by the Kimura two parameter (Kimura 1980), using MEGA 5.1 software. Statistical analyses of phylogenetic trees were determined by 1,000 bootstrap replicates.

\section{RESULTS}

Pathological findings. Warts were observed at the lips and nose of two dogs, at the mucous membranes of the oral cavity of one, and at the lips and the left and right hind limbs of the other. In one dog, the warts resulted in deformation of the nasal cavity (Fig.1). Grossly, all collected tissues were exophytic cutaneous warts. The histopathological findings of all submitted tissue sections were similar, being charac-

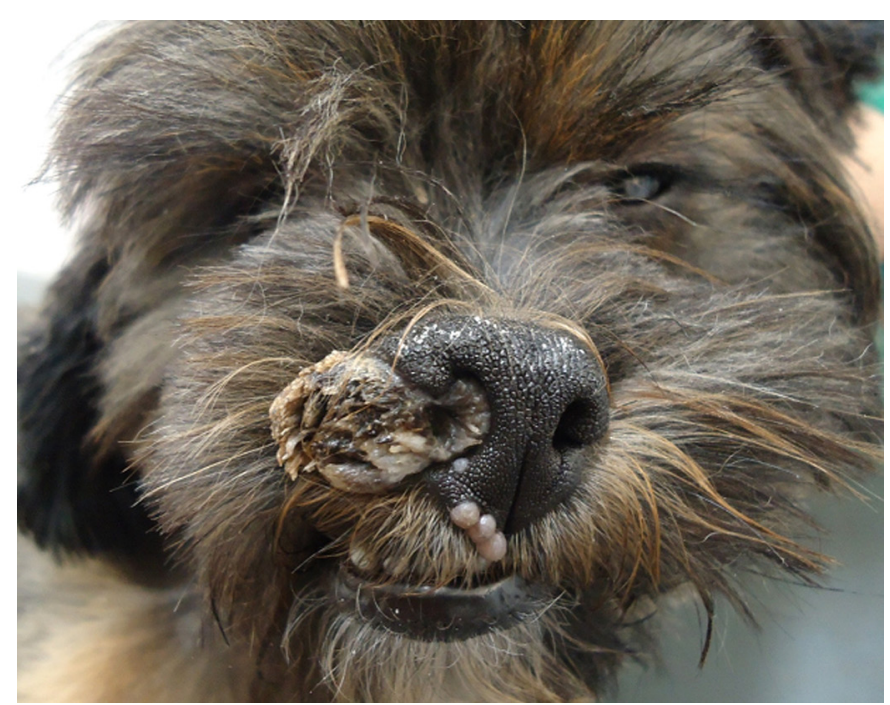

Fig.1. Mongrel dog with canine viral papillomatosis at the lips and nose that resulted in nasal deformity. 


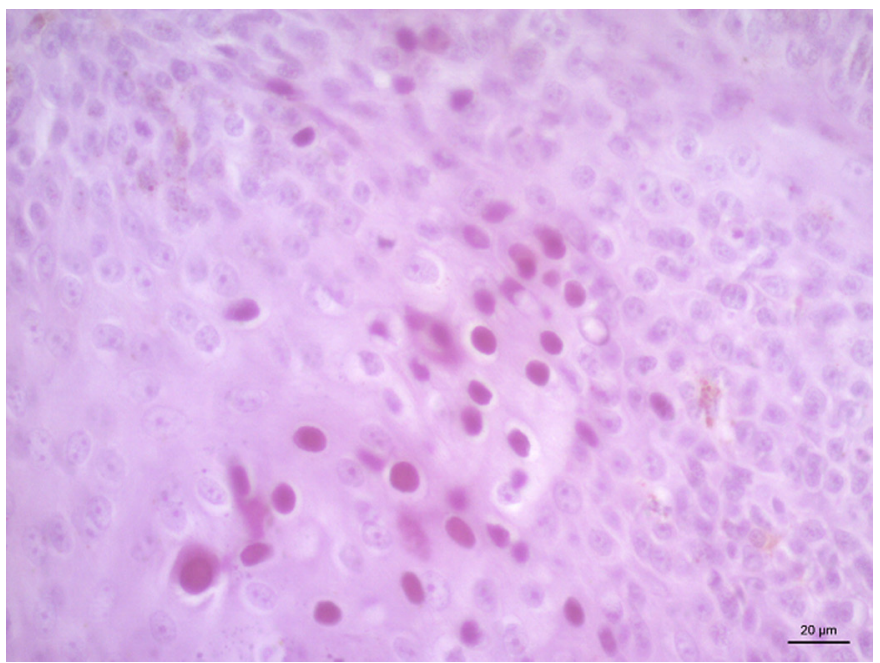

Fig.2. Canine viral papillomatosis; observe the large accumulation of giant keratohyalin granules and discrete cytopathic effect within the stratum granulosum. Hematoxylin and Eosin stain, bar $20 \mu \mathrm{m}$.

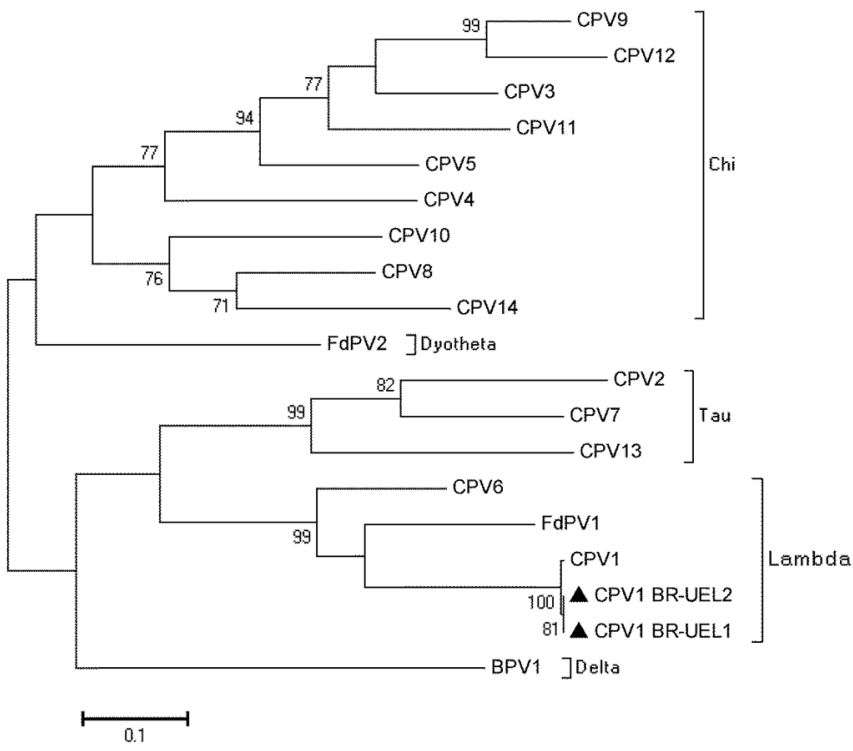

Fig.3. Phylogenetic tree obtained by the maximum-likelihood method based on the nucleotide sequences of the CPV L1 gene. Bootstrap values are indicated when $50 \%$ as a percentage was obtained from 1,000 replications. The CPVs strains are highlighted (filled triangles) as CPV1 BR-UEL1 and 2 (GenBank accession numbers: KF199909 and KF199910). BPV1 was included as outgroup. PV sequence names are labeled as BLAST identification. The scale bar represents a genetic distance of 0.1 substitutions per site.

terized as viral papillomas. There was hyperkeratotic hyperplasia with the forming of finger-like projections of the hyperplastic squamous epithelium, the occurrence of giant keratohyalin granules within the stratum granulosum, and discrete koilocytosis of the stratum spinosum and granulosum (Fig. 2); distinct basophilic intranuclear inclusion bodies were not observed.

Molecular characterization of canine papillomavirus. Amplicons of the expected length (approximately
$480 \mathrm{bp}$ ), were amplified from all samples by the PCR assay; negative controls yielded no amplified products. Six of these sequences were similar with $100 \%$ identity among them; however, one nucleotide sequence from an oral papilloma had $99.7 \%$ identity with the other sequences from this study. The nucleotide sequences obtained during this study demonstrated $99.3 \%$ to $100 \%$ similarity with other sequences of CPV1 available at GenBank.

The strains identified in this study and used during the sequence alignment were designated as CPV1 BR/ UEL1 and CPV1 BR/UEL2 (GenBank accession numbers: KF199909 and KF199910). Analysis of the phylogenetic tree demonstrated that the Brazilian strains of CPV1 clustered with known strains of the Lambdapapillomavirus, particularly with those of CPV1 (Fig. 3).

The GenBank accession numbers of the strains used are: BPV1 (X02346), CPV1 (L22695), CPV2 (AY722648), CPV3 (NC_008297), CPV4 (NC_010226), CPV5 (FJ492743), CPV6 (FJ592744), CPV7 (FJ492743), CPV8 (HM796884), CPV9 (NC_016074), CPV10 (NC_016075), CPV11 (NC_016076), CPV12 (JQ754321), CPV13 (JX141478), CPV14 (JQ701802), FdPV1 (NC_004765), and FdPV2 (EU796884).

\section{DISCUSSION}

The gross and histopathological features of the cutaneous lesions are consistent with those described in canine oral papillomas (Gross et al. 2005, Ginn et al. 2007), since the cytoplasmic alterations observed during this study are typical of viral-induced cytopathic effects and are diagnostic for this lesion (Gross et al. 2005, Lange \& Favrot 2011). Similar histopathological findings were recently described in dogs with oral papillomavirus from Korea identified by molecular biology (Yhee et al. 2010) and in dogs from Brazil characterized by immunohistochemistry for Papillomavirus (Bianchi et al. 2012), however the last investigation did not specify the PV type identified in dogs from Brazil.

Confirmation of the participation of CPV1 within these lesions was obtained due to the successful amplification of viral DNA with subsequent sequencing of the partial L1 gene of CPV1; similar results have been described (Yhee et al. 2010). However, it must be highlighted that the degenerate primers (FAP 59 and FAP 64), originally designed to detect a broad range of cutaneous HPVs (Forslund et al. 1999), successfully amplified the partial fragment of the CPV1 L1 gene, suggesting that direct sequencing is an important tool for the molecular characterization of PV types of infectious agents.

Bianchi et al. (2012) using monoclonal Papillomaviridae antibodies, by immunohistochemistry, demonstrated that Papillomavirus was present in $83.3 \%$ (20/24) of papilloms from dogs in Rio Grande do Sul. However, to the best of the authors' knowledge, the present study represents the first molecular characterization of CPV1 associated with papillomatosis in dogs from Brazil.

The importance of this study was to characterize the PVs types present in dogs of Brazil, since immunity is typespecific, and CPV1 L1 virus like-particles vaccines can protect dogs against the development of mucosal papillomas (Suzich et al. 1995, Stanley et al. 2001), while the immu- 
nity can be passively transferred to offsprings (Nicholls \& Stanley 2000). Additionally, considering the great diversity of canine PVs, the efficiency of degenerate primers, as demonstrated during this investigation, facilitate the identification of putative new PV types (Zaugg et al. 2005, Lange et al. 2013). Hence, the knowledge of the CPV types circulating in local canine populations is essential for the establishment of control measures.

Acknowledgments.- The authors thank the following Brazilian Institutes for financial support: the National Counsel of Scientific and Technological Development (CNPq), the Brazilian Federal Agency for Support and Evaluation of Graduate Education (CAPES), Financing of Studies and Projects (FINEP), and the Araucária Foundation (FAP/PR). A.A Alfieri, S.A. Headley and A.F. Alfieri are recipients of CNPq fellowships.

\section{REFERENCES}

Bernard H.U., Burk R.D., Chen Z., Van Doorslaer K., Zur Hausen H. \& De Villiers E.M. 2010. Classification of papillomaviruses (PVs) based on 189 PV types and proposal of taxonomic amendments. Virology 401:70-79.

Bianchi M.V., Casagrande R.A., Watanabe T.T.N., Wouters A.T.B., Wouters F., Boos G.S., Menegat M.B. \& Driemeier D. 2012. Canine papillomatosis: a retrospective study of 24 cases. Pesq. Vet. Bras. 32:653-657.

Brandes K., Fritsche J., Mueller N., Koerschgen B., Dierig B., Strebelow G. \& Teifke J.P. 2009. Detection of canine oral papillomavirus DNA in conjuctival epithelial hyperplastic lesions of three dogs. Vet. Pathol. 46:34-38.

Campo M.S. 2002. Animal models of papillomavirus pathogenesis. Virus Res. 89:249-261.

Claus M.P., Vivian D., Lunardi M., Alfieri A.F. \& Alfieri A.A. 2007. Phylogenetic analysis of bovine papillomavirus associated with skin warts in cattle herds from the state of Paraná. Pesq. Vet. Bras. 27:314-318.

De Villiers E.M., Fauquet C., Broker T.R., Brenard H.U. \& Zur Hausen H. 2004. Classification of papillomaviruses. Virol. 324:17-27.

Forslund O., Antonsson A., Nordin P. \& Hansson B.G. 1999. A broad range of human papillomavirus types detected with a general PCR method suitable for analysis of cutaneous tumours and normal skin. J. Gen. Virol. 80:237-243

Ginn P.E., Mansell J.E.K.L. \& Rakich P.M. 2007. Skin and appendages, p. 748751. In: Maxie M.G. (Ed.), Jubb, Kennedy, and Palmer's Pathology of Domestic Animals. Vol.1. $5^{\text {th }}$ ed. Elsevier, Philadelphia.

Gross T.L., Ihrke P.J., Walder E.J. \& Affolter V.K. 2005. Skin Diseases of the Dog and Cat: clinical and histopathologic diagnosis. $2^{\text {nd }}$ ed. Blackwell, Oxford. 932p.
Isegawa N., Nakano K., Ohta M., Shirasawa H., Tokita H. \& Simizua B. 1994. Cloning and sequencing of the $\mathrm{Ll}$ gene of canine oral papillomavirus. Gene 146:261-265.

Kimura M. 1980. A simple method for estimating evolutionary rate of base substitutions through comparative studies of nucleotide sequences. J. Mol. Evol. 16:11-120

Lange C.E., Tobler K., Brandes K., Breithard K., Ordeix L., Von Bomhard W. \& Favrot C. 2009. Canine inverted papillomas associated with DNA of four different papillomaviruses. Vet. Dermatol. 21:287-291.

Lange C.E. \& Favrot C. 2011. Canine papillomaviruses. Vet. Clin. Small Anim. 41:1183-1195.

Lange C.E., Ackermann M., Favrot C. \& Tobler K. 2012. Entire genomic sequence of novel canine papillomavirus type 13. J. Virol. 86:1022610227.

Lange C.E., Tobler K., Schraner E.M., Vetsch E., Fischer N.M., Ackermann M. \& Favrot C. 2013. Complete canine papillomavirus life cycle in pigmented lesions. Vet. Microbiol. 162:388-395.

Nicholls P.K. \& Stanley M.A. 2000. The immunology of animal papillomaviruses. Vet. Immunol. Immunopathol. 73:101-127.

Souza T.M., Fighera R.A., Irigoyen L.F. \& Barros C.S.L. 2006. Retrospective study on 761 canine skin tumors. Ciência Rural 32:555-560.

Stanley M.A., Moore R.A., Nicholls P.K., Santos E.B., Thomsen L., Parry N., Walcott S. \& Gough G. 2001. Intra-epithelial vaccination with COPV L1 DNA by particle-mediated DNA delivery protects against mucosal challenge with infectious COPV in beagle dogs. Vaccine 19:2783-2792.

Suzich J.A., Ghim S.J., Palmer-Hill F.J., White W.I., Tamura J.K., Bell J.A., Newsome J.A., Jenson A.B. \& Schlegel R. 1995. Systemic immunization with papillomavirus L1 protein completely prevents the development of viral mucosal papillomas. Immun. 92:11553-11557.

Teifke J.P., Löhr C.V. \& Shirasawa H. 1998. Detection of canine oral papillomavirus-DNA in canine oral squamous cell carcinomas and p53 overexpressing skin papillomas of the dog using the polymerase chain reaction and non-radioactive in situ hybridization. Vet. Microbiol. 60:119-130.

Yhee J.Y., Kwon B.J., Kim J.H., Yu C.H., Im K.S., Lee S.S, Lyoo Y.S., Chang B.J. \& Sur J.H. 2010. Characterization of canine oral papillomavirus by histopathological and genetic analysis in Korea. J. Vet. Sci. 11:21-25.

Yuan H., Luff J., Zhou D., Wang J., Moore P. \& Schlegel R. 2012a. Complete genome sequence of canine papillomavirus type 9. J. Virol. 86:11-12.

Yuan H., Luff J., Zhou D., Wang J., Moore P. \& Schlegel R. 2012b. Complete Genome Sequence of Canine Papillomavirus Type 12. Pathol. Unpublished data. <http://www.ncbi.nlm.nih.gov/nuccore/388542469>

Zaugg N., Nespeca G., Hauser B., Ackermann M. \& Favrot C. 2005. Detection of novel papillomaviruses in canine mucosal, cutaneous and in situ squamous cell carcinomas. Vet. Dermatol. 16:290-298. 